\section{(-) OPEN ACCESS}

\title{
Patient with Niemann-Pick disease type C: over 20 years' follow-up
}

\author{
Kazuo Abe, ${ }^{1,2}$ Norio Sakai ${ }^{3}$
}

\section{'Department of Community} Health Medicine, Hyogo College of Medicine Graduate School of Medicine, Nishinomiya, Japan ${ }^{2}$ Division of Neurology, Hyogo College of Medicine Graduate School of Medicine, Nishinomiya, Japan ${ }^{3}$ Department of Pediatrics, Osaka University Graduate School of Medicine, Suita, Japan

Correspondence to Professor Kazuo Abe, abe_neurology@mac.com

Accepted 10 August 2017 CrossMark

To cite: Abe K, Sakai N. BMJ Case Rep Published Online First: [please include Day Month Year]. doi:10.1136/ bcr-2017-220134

\section{SUMMARY}

We report a 37-year-old woman with Niemann-Pick disease type C (NPC) 1. At the age of 8 years, she presented slow running followed by both fingers dystonia at the age of 10 years. At the age of 16 years, she developed declined scholastic achievement. On her first visit at the age of 17 years, she showed dystonia, ataxic gait and vertical supranuclear gaze palsy. We suspected it was NPC. She presented atrophies in the frontal lobes, brainstem and cerebellum in a brain MRI. She presented hepatomegalies and splenomegalies in an abdominal CT. At the age of 26 years, she undertook perpetually tracheal fistula because of recurrent aspiration pneumonia. Diagnosis of NPC1 was made by filipin staining and existence of foamy cells in the bone marrow and NPC1 gene analysis. We obtained informed consent of genetic analysis. Miglustat therapy was started at the age of 32 years. Improvements in swallowing capacity and in muscle tonus were seen.

\section{BACKGROUND}

Niemann-Pick disease type C (NPC) is an autosomal recessive neurovisceral lysosomal storage disorder resulting from mutations of either the NPC1 or the NPC2 gene, showing a wide spectrum of clinical phenotypes and a highly variable age at diagnosis, and most patients have normal routine examinations (MRI, cerebrospinal fluid, electrophysiology and so on). ${ }^{1-5}$ Thus, its diagnosis is often a challenge, delaying the start of treatment for several years.

We report a 37-year-old woman with NPC1 whom we continuously follow for over 20 years.

\section{CASE PRESENTATION}

Patient is a 37-year-old woman. At the age of 8 years, she presented slow running followed by both fingers dystonia at the age of 10 years. At the age of 16 years, she developed declined scholastic achievement.

On her first visit at the age of 17 years, she showed dystonia in all limbs, dysarthria, ataxic gait and vertical supranuclear gaze palsy (VSGP). On neurological examinations, she had VSGP without horizontal gaze palsy and abnormal coordination predominantly in lower limbs but had normal cranial nerve function and normal muscle strength. She had normal autonomic functions. Because of VSGP and dystonia, we suspected it was NPC. She presented atrophies in the frontal lobes, brainstem and cerebellum in a brain MRI (figure 1). She presented hepatomegalies and splenomegalies in an abdominal CT (figure 2).

Following MRIs showed developing atrophies in the brain and diffuse T2 high signals in the white matter. Electroencephalographic (EEG) matched criteria for diffuse generalised encephalopathy. Her gait disturbances due to dystonia and cerebellar ataxia gradually developed but could walk without assist until the age of 21 years. Her VSGP and dystonia gradually developed, and her horizontal eye movements was normal. She experienced frequent falls, and she eventually used wheel chair at the age of 22 years. She gradually developed difficulty in swallowing, and a percutaneous endoscopic gastrostomy was initiated. At the age of 26 years, she undertook perpetually tracheal fistula because of recurrent aspiration pneumonia. She could communicate with her facial expression when she was asked.

\section{DIFFERENTIAL DIAGNOSIS}

NPC is characterised by heterogeneous and oligosymptomatic presentation of visceral, neurological and psychiatric manifestations, making for difficult and often delayed diagnosis. Diagnosis of NP-C is made via physical assessment of the patient, biochemical tests involving filipin staining of skin fibroblasts and genetic sequencing of the NPC1 and NPC2 mutations. For physicians unfamiliar with NPC, at this time, the NPC Suspicion Index screening tool was developed by an international panel of NPC clinical experts.

\section{TREATMENT}

Miglustat was first approved for treatment of progressive neurological deterioration in children and adults with NPC based on preclinical evidence, a randomised controlled trial, long-term extension studies and a retrospective cohort study.

\section{OUTCOME AND FOLLOW-UP}

Diagnosis of NPC1 was made by filipin staining (figure 3A) and existence of foamy cells (figure 3B) in the bone marrow, and NPC1 gene analysis: c. 2186 G>A (p.G729E), c.2374-2A>G. We obtained informed consent of genetic analysis.

Miglustat therapy ${ }^{6-8}$ was started at the age of 32 years. Improvements in swallowing capacity and in muscle tonus were observed. She developed constipation, but no other adverse reactions were observed for 4 years after prescription of miglustat. 


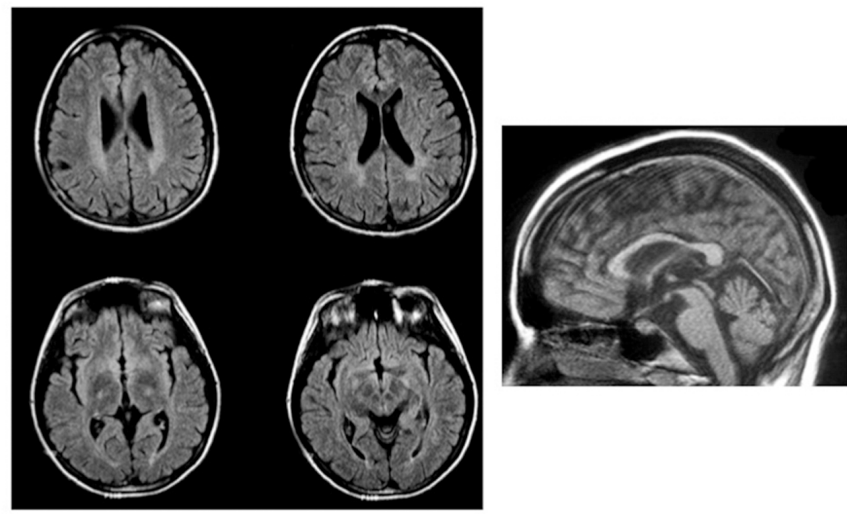

Figure 1 A brain MRI showed atrophies in the frontal lobes, brainstem and cerebellum.

Now she used wheelchair with assist but can stand with assist

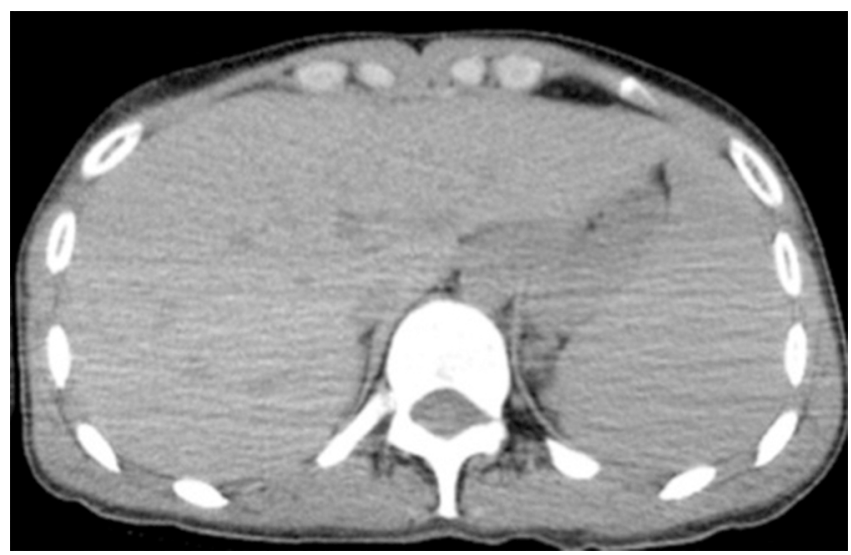

Figure 2 An abdominal CT showed hepatomegalies and splenomegalies.
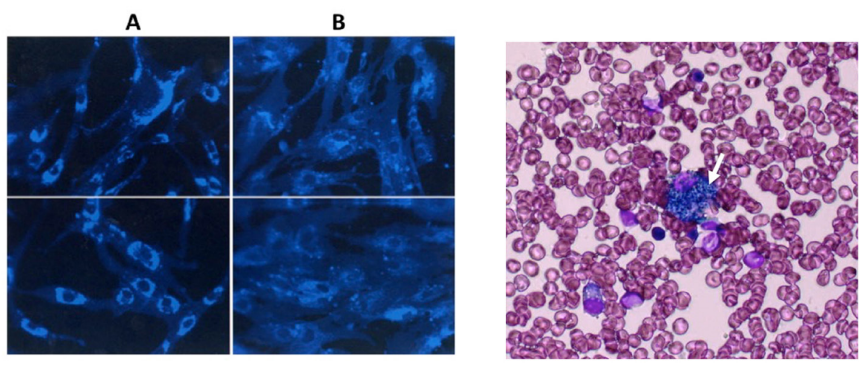

Figure 3 Filipin-stained cultured skin fibroblasts from a control (A) and from the patient with the classic form of Niemann-Pick disease type C (B). In (B), the increase of fluorescence intensity that reflects vacuolar accumulation of unesterified cholesterol in the perinuclear region of the cells is evident. Original magnifications: $200 \times$. Bone marrow biopsy showing increased amount of macrophages, some of them with foamy cytoplasm (arrow). May-Grunwald-Giemsa staining; magnification: $400 \times$. for minutes. She had vertical supranuclear gaze palsy without horizontal gaze palsy and abnormal coordination predominantly in lower limbs but had normal cranial nerve function and normal muscle strength. She can express her will by facial expression and by preserved horizontal eye movements.

\section{DISCUSSION}

Miglustat therapy ${ }^{6-8}$ improved swallowing capacity and muscle tonus. She developed constipation, but no other adverse reactions were observed for 4 years after prescription of miglustat. We believe that prescription of miglustat seems to be useful for improving and preserving her neurological signs and symptoms.

Among the various neurological signs, VSGP and dystonia should be considered as highly important signs for juvenile/ adult onset NPC diagnosis. Because prescription of miglustat is helpful, early treatment in the disease course shows improved responses, highlighting the need for rapid diagnosis. In patients with atypical symptomology, a careful examination for VSGP is critical to enhance diagnostic accuracy in potential NPC.

\section{Learning points}

- Niemann-Pick disease type C (NPC) is a rare disease.

- Diagnosis of NPC is somewhat difficult.

- Miglustat may be effective.

Contributors KA: project development, data collection and manuscript writing. NS critical review of the manuscript.

Competing interests None declared.

Patient consent Obtained from guardian.

Provenance and peer review Not commissioned; externally peer reviewed.

Open Access This is an Open Access article distributed in accordance with the Creative Commons Attribution Non Commercial (CC BY-NC 4.0) license, which permits others to distribute, remix, adapt, build upon this work non-commercially, and license their derivative works on different terms, provided the original work is properly cited and the use is non-commercial. See: http://creativecommons.org/ licenses/by-nc/4.0/

(C) BMJ Publishing Group Ltd (unless otherwise stated in the text of the article) 2017. All rights reserved. No commercial use is permitted unless otherwise expressly granted.

\section{REFERENCES}

1 Vanier MT, Millat G. Niemann-Pick disease type C. Clin Genet 2003;64:269-81.

2 Patterson MC. A riddle wrapped in a mystery: understanding Niemann-Pick disease, type C. Neurologist 2003;9:301-10.

3 Lachmann RH, te Vruchte D, Lloyd-Evans E, et al. Treatment with miglustat reverses the lipid-trafficking defect in Niemann-Pick disease type C. Neurobiol Dis 2004;16:654-8.

4 Cox TM. Substrate reduction therapy for lysosomal storage diseases. Acta Paediatr Supp/ 2005;94:69-75

5 Crespi J, Bråthen G, Quist-Paulsen P, et al. Facial Dystonia with Facial Grimacing and Vertical Gaze Palsy with "Round the Houses" Sign in a 29-Year-Old Woman. Neuroophthalmology 2016;40:31-4.

6 Fecarotta S, Romano A, Della Casa R, et al. Long term follow-up to evaluate the efficacy of miglustat treatment in Italian patients with Niemann-Pick disease type C. Orphanet J Rare Dis 2015:10:22

7 Piroth T, Boelmans K, Amtage F, et al. Adult-Onset Niemann-Pick Disease Type C: Rapid Treatment Initiation Advised but Early Diagnosis Remains Difficult. Front Neurol 2017;8:108

8 Masingue M, Adanyeguh I, Nadjar Y, et al. Evolution of structural neuroimaging biomarkers in a series of adult patients with Niemann-Pick type $C$ under treatment. Orphanet J Rare Dis 2017;12:22 
Copyright 2017 BMJ Publishing Group. All rights reserved. For permission to reuse any of this content visit http://group.bmj.com/group/rights-licensing/permissions.

BMJ Case Report Fellows may re-use this article for personal use and teaching without any further permission.

Become a Fellow of BMJ Case Reports today and you can:

- Submit as many cases as you like

- Enjoy fast sympathetic peer review and rapid publication of accepted articles

- Access all the published articles

- Re-use any of the published material for personal use and teaching without further permission

For information on Institutional Fellowships contact consortiasales@bmjgroup.com

Visit casereports.bmj.com for more articles like this and to become a Fellow 